\title{
EFFECT OF LONG-TERM EXPOSURE TO TRAFFIC NOISE ON AUDITORY TEMPORAL RESOLUTION OF TRAFFIC POLICE: A PRELIMINARY STUDY
}

\author{
Vipin Ghosh, Sharmada Kumaraswamy, Meera Rachel Anil \\ Department of Speech and Hearing, JSS Institute of Speech and Hearing, Mysore, India \\ Corresponding author: Vipin Ghosh, Lecturer in Audiology, JSS Institute of Speech and Hearing, \\ M G Road, Mysore-570004, Karnataka, India, e-mail: vipinghosh78@gmail.com
}

\begin{abstract}
Background: Prolonged exposure to occupational noise can lead to various audiological and non-audiological effects. The present study is a preliminary investigation of the temporal resolution ability of traffic police officers who had a history of exposure to traffic noise for at least 5 years.
\end{abstract}

Material and methods: The study focused on an experimental group of 20 traffic police officers and a control group of 20 agematched individuals without noise exposure. A gap detection test (GDT) and a test of modulation detection thresholds for sinusoidally amplitude modulated noise (TMTF) at $8 \mathrm{~Hz}, 20 \mathrm{~Hz}$, and $60 \mathrm{~Hz}$ were administered to all the participants.

Results: ANOVA was carried out to check for significant different in performance between the groups, which suggested a main effect of groups. A further $t$-test was done and no significant difference $(p>0.05)$ between the groups in test performance was observed, suggesting that temporal resolution is not significantly affected in traffic police exposed to traffic noise.

Conclusions: The present study findings may be attributed to various factors that control the effect of noise on humans. These factors are discussed. However, the population cannot be considered as free from noise-related harms since nonauditory effects of traffic noise, including sleep disturbances, annoyance, hypertension, and stress, have been reported in earlier studies. More research is needed to clarify the situation.

Key words: noise-induced hearing loss • temporal resolution

IMPACTO DE UNA EXPOSICIÓN PROLONGADA AL RUIDO DEL TRÁFICO SOBRE LA RESOLUCIÓN TEMPORAL EN LOS POLICÍAS DE TRÁFICO: ESTUDIO PRELIMINAR

\section{Resumen}

Introducción: Una exposición prolongada al ruido en el lugar de trabajo afecta el funcionamiento del individuo, incluido el área auditiva. El presente trabajo muestra datos preliminares relativos a la resolución temporal del sistema auditivo en los empleados de la policía de tráfico que han sufrido episodios temporadas de exposición al ruido del tráfico de al menos cinco años de duración.

Materiales y métodos: Se han comparado los resultados obtenidos en el grupo examinado, formado por 20 oficiales de policía de tráfico con los resultados provenientes del grupo de control de 20 personas seleccionadas en cuanto a la edad que no han pasado por episodios de exposición al ruido del tráfico. Los individuos examinados han sido sometido al test de los umbrales de detección de brechas (GDT) y a la prueba de función de transferencia de modulación (TMTF) para el ruido con amplitud modulada de tipo sinusoidal para 8,20 y $80 \mathrm{~Hz}$.

Resultados: Para comprobar la importancia de las diferencias entre los resultados de los dos grupos se utilizó la técnica del Análisis de la Varianza (ANOVA), por la cual se estableció el resultado principal de cada grupo. A continuación se efectuó la prueba $t$ de Student, que para el nivel de probabilidad $p>0,05$ no ha demostrado diferencias importantes entre los resultados de pruebas realizadas en los dos grupos. Estos resultados sugieren que la exposición al ruido del tráfico no afecta de manera importante la resolución temporal en los policías de tráfico.

Conclusiones: Los resultados del estudio comentado podían haber sido influenciados por múltiples factores que regulan el impacto del ruido sobre el individuo, los que se han debatido en el presente trabajo. No obstante, no se debe descartar por completo el impacto devastador del ruido sobre el funcionamiento psicofísico general del individuo, descrito en referencias 
anteriores, incluidos los trastornos del sueño, la irritabilidad, la tensión alta y el estrés. Para una verificación mas profunda hay que realizar pruebas adicionales.

Palabras clave: trauma acústico • fenómeno de reclutamiento

\section{ВЛИЯНИЕ ДЛИТЕЛЬНОГО ВОЗДЕЙСТВИЯ УЛИЧНОГО ШУМА НА ВРЕМЕННУЮ РАЗРЕШАЮЩУЮ СПОСОБНОСТЬ У АВТОДОРОЖНОЙ ПОЛИЦИИ: ПРЕДВАРИТЕЛЬНОЕ ИССЛЕДОВАНИЕ}

\section{Изложение}

Введение: Длительное воздействие шума на рабочем месте влияет на функционирование человеческой единицы, в т.ч. на сферу слуха. Данная работа представляет предварительные данные, касающиеся временной разрешающей способности слуха сотрудников автодорожной полиции, которые подвергались воздействию уличного шума в течение как минимум пяти лет.

Материал и метод: Было сделано сравнение результатов, полученных у исследуемой группы, состоящей из 20 сотрудников автодорожной полиции, с результатами контрольной группы из 20 человек, подобранных по возрасту, у которых не имелось эпизодов воздействия уличного шума. У исследуемых лиц были проведены тест обнаружения паузы (GDT) и тест обнаружения порога модуляции для шума с амплитудой, модулированной синусоидально (ТМТF), для 8, 20 и 80 Гц.

Результаты: С целью проверки, насколько существенна разница в результатах двух групп, использовался метод дисперсионного анализа (ANOVA), который показал главный результат каждой группы. Затем был проведён $t$-тест (критерий Стьюдента), который на уровне вероятности $p>0,05$ не показал существенных различий между результатами тестов двух групп. Данные результаты позволяют предположить, что воздействие уличного шума не оказывает значительного влияния на временную разрешающую способность у автодорожной полиции.

Выводы: На результаты данного исследования могли повлиять различные факторы, регулирующие воздействие шума на единицу, которые были проанализированы в работе. Тем не менее не следует совсем исключать пагубного воздействия шума на общее психофизическое функционирование человеческой единицы, описанного в других исследованиях, в том числе в виде нарушений сна, раздражения, гипертонии и стресса. Для дальнейшей проверки следует провести дополнительные исследования.

Ключевые слова: акустическая травма • явление рекрутмента (recruitment)

\section{WPŁYW DŁUGOTRWAŁEGO NARAŻENIA NA HAŁAS ULICZNY NA ROZDZIELCZOŚĆ CZASOWĄ U POLICJI DROGOWEJ: BADANIE WSTĘPNE}

\section{Streszczenie}

Wprowadzenie: Przedłużona ekspozycja na hałas w miejscu pracy przekłada się na funkcjonowanie jednostki, w tym sferę słuchową. Niniejsza praca przedstawia wstępne dane dotyczące rozdzielczości czasowej słuchu u pracowników policji drogowej, u których odnotowano co najmniej pięcioletnie epizody narażenia na hałas uliczny.

Materiał i metody: Porównano wyniki uzyskane u grupy badanej, składającej się z 20 funkcjonariuszy policji drogowej, z wynikami grupy kontrolnej 20 osób dobranych pod względem wieku, u których nie wystąpiły epizody narażenia na hałas uliczny. U badanych wykonano test wykrywania przerw (GDT) oraz test wykrywania progu modulacji dla szumu o amplitudzie modulowanej sinusoidalnie (TMTF) dla 8,20 i $80 \mathrm{~Hz}$.

Wyniki: Celem sprawdzenia istotności różnic między wynikami obu grup wykorzystano metodę analizy wariancji (ANOVA), która wskazała na główny wynik każdej grupy. Następnie wykonano test $t$-Studenta, który na poziomie prawdopodobieństwa $p>0,05$ nie wykazał istotnych różnic między wynikami testów u obu grup. Wyniki te sugerują, iż ekspozycja na hałas uliczny nie wpływa w znaczący sposób na rozdzielczość czasową u policji drogowej.

Wnioski: Na wyniki opisywanego badania wpływ mogły mieć wielorakie czynniki regulujące wpływ hałasu na jednostkę, które omówiono w pracy. Niemniej jednak, nie należy całkowicie wykluczać zgubnego oddziaływania hałasu na ogólne funkcjonowanie psychofizyczne jednostki, opisywanego we wcześniejszych doniesieniach, w tym: zaburzenia snu, rozdrażnienie, nadciśnienie i stres. Celem dalszej weryfikacji należy przeprowadzić dodatkowe badania.

Słowa kluczowe: uraz akustyczny • zjawisko recruitment 


\section{Background}

Occupational noise is well known for its nonauditory and auditory effects. The nonauditory effects include sleep disturbances, annoyance, cardiovascular disease, and cognitive deficits. It is also a major cause of hearing loss due to the dysfunction of hair cells within the cochlea [1]. The effect of noise on peripheral auditory abilities can be temporary, as in temporary threshold shift, or permanent, as in permanent threshold shift. In addition, earlier studies have also documented temporal processing difficulties as a consequence of occupational noise exposure [2]. Temporal processing can be defined as the perception of sound or of the alteration of sound within a restricted or defined time domain. Voice identification, pitch perception, and speech perception is reported to be affected if the temporal processing is altered. Precise temporal processing is required to process the temporal aspects of a signal which is essential to perceive it in quiet as well as in noisy environments. Temporal processing can be studied using various test procedures. The gap detection test (GDT) and the temporal modulation transfer function (TMTF) are the most commonly used procedures to check for temporal processing acuity. Gap detection testing taps the ability of an individual to detect a temporal gap between two stimuli. The threshold at which the gap is sufficiently wide to be detected is considered the gap detection threshold. TMTF requires the subject to identify modulations in a stimulus. A number of earlier studies have made use of these procedures to study the effect of noise on temporal processing and speech perception in quiet and under adverse listening conditions.

The GDT, TMTF, duration pattern test, and speech in noise test have been used in an earlier study on train drivers to understand the effect of noise on the speech perception and temporal processing abilities in them [2]. Poor temporal processing skills partially accounted for speech perception difficulties under adverse listening conditions irrespective of their hearing capability. A similar finding was reported in teachers [3]. In teachers who were exposed to class room noise for a long time, the reported effect was temporal processing difficulties and reduced speech perception in the presence of noise. However, similar studies are limited in the literature.

Among different noise sources, transport noise is a major one, and road traffic noise is the most common type. Various studies have reported the nonauditory effects of prolonged exposure to traffic noise including sleep disturbance, annoyance, hormonal imbalance, and psychological stress [4]. Traffic police officers work amidst road traffic and are exposed to traffic noise throughout their duty hours. Hence, attempts have been made to understand the health implications of traffic police officers. It is reported [5] that the incidence of naso-pharyngitis, arthropathy, photosensitive dermatitis, heat stroke, and noise-induced hearing loss in traffic police who work outdoor among traffic was higher than that of police who work indoors. Moreover, traffic police are reported to be 1.4 times more likely than civil servants to develop noise-induced hearing loss [6]. However, there is a lack of consistent literature on the effect of traffic noise on the auditory system of these individuals, suggesting the need to study the auditory abilities of these individuals, including their temporal processing abilities. Hence the present study was planned to investigate the effect of long-term exposure of traffic noise on the temporal resolution abilities of traffic police.

The study investigated their performance on the gap detection test (GDT) and the modulation detection thresholds for sinusoidally amplitude modulated noise (TMTF) at $8 \mathrm{~Hz}, 20 \mathrm{~Hz}$, and $60 \mathrm{~Hz}$, and compared it with an agematched control group.

\section{Materials and methods}

\section{Participants}

A total of 40 individuals participated in the study and were divided into 2 groups. Group 1 served as the experimental group and consisted of 20 traffic police officers within the age range of $25-55$ years with a mean age of 38.9 years (standard deviation 5.61). All the participants in Group 1 had been exposed to traffic noise during their duty period ( 8 hours per day) for a minimum of 5 years. Group 2 , the control group, consisted of 20 age-matched adults with a mean age of 35.75 (SD 4.78) years. No participant in Group 2 reported continuous or high level noise exposure. All participants were recruited on a non-payment basis and provided written informed consent.

\section{Procedure}

Detailed case histories were taken prior to testing to rule out otological complaints. Hearing levels of all subjects, including the traffic police officers, had bilateral pure tone thresholds within $25 \mathrm{~dB}$ HL, confirmed by audiological screening with a Menor clinical audiometer connected to TDH 39 headphones.

Psychophysical tests involved a gap detection test (GDT) and modulation detection thresholds for sinusoidally amplitude modulated noise (TMTF) at 8, 20, and $60 \mathrm{~Hz}$ modulation rates. These tests were carried out using a maximum likelihood procedure with the MLP toolbox of Matlab 2010 [7]. A three-interval alternated forcedchoice method was used and the participant was instructed to identify the variable stimulus out of the three presented. The stimulus used for GDT testing was $750 \mathrm{~ms}$ Gaussian noise with a temporal gap inserted in the center and having $0.5 \mathrm{~ms}$ raised cosine ramps at the beginning and end of the temporal gap. Depending on the responses of the subject the duration of the gap was varied. Amplitude modulated Gaussian noise was used for TMTF. In TMTF the subject responses decided the variations in depth of modulation. Modulation detection threshold (dB) of each participant was thus obtained. A laptop computer was used to deliver the stimuli monaurally through Sennheiser HD220 circumaural headphones. The output of the headphone was measured and controlled using a B\&K 2268 sound level meter. The test stimuli were presented to the participant at his most comfortable level. All tests were carried out in a silent room.

A commercially available statistical tool, Statistical Package for Social Sciences (SPSS) version 16.0 was used for statistical analysis. Descriptive statistics along with independent 
Table 1. Means and standard deviations (SD) of gap detection thresholds (in ms) and modulation detection thresholds (in $\mathrm{dB}$ ) for both the control and experimental groups

\begin{tabular}{lccccc}
\hline \multirow{2}{*}{ Test } & \multicolumn{2}{c}{ Control group (40 ears) } & \multicolumn{2}{c}{ Experimental group (40 ears) } \\
\cline { 2 - 5 } & Mean & SD & Mean & SD \\
\hline GDT $(\mathrm{ms})$ & 4.13 & 2.0 & 5.02 & 2.20 \\
\hline TMTF & & & & \\
\hline $8 \mathrm{~Hz}$ & -34.75 & 12.1 & -28.86 & 4.9 \\
\hline $20 \mathrm{~Hz}$ & -36.37 & 2.14 & -29.61 & 11.66 \\
\hline $60 \mathrm{~Hz}$ & -31.92 & 4.89 & -29.59 & 4.37 \\
\hline
\end{tabular}

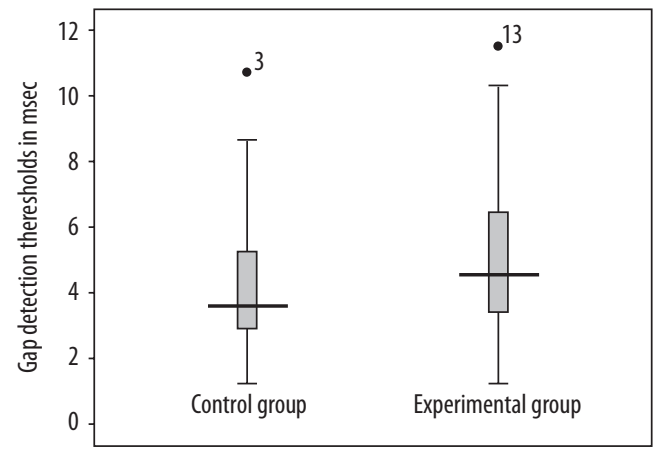

Figure 1. Gap detection thresholds (in ms) in noise-exposed participants and the control group. Error bars indicate standard deviations and circles indicate suspected outliers

t-test and one-way ANOVA were carried out to study the findings and investigate the differences between control and experimental groups.

\section{Results}

Descriptive statistics including means and standard deviations (SD) were calculated for the scores of GDT and TMTF. The values are given in Table 1 . Figure 1 is a plot of the gap detection thresholds and Figure 2 shows the modulation detection thresholds.

It can be observed that the mean scores in the experimental group are slightly elevated compared with the control group. In order to check the statistical significance of such a difference, an ANOVA was carried out. The results suggested a main effect of groups. Further, a $t$-test was carried out which revealed that the GDT scores did not vary significantly between the groups $(t=-1.86, p>0.05)$. Similarly, the results suggest that the modulation detection thresholds at 8,20 , and $60 \mathrm{~Hz}$ were not significantly different between the groups $(t=-2.85, p>0.05 ; t=-3.60, p>0.05$; $t=-2.26, p>0.05)$. The difference in parametric versus non parametric tests may be attributed to the small sample size and standard deviation.

\section{Discussion}

The present study compared the temporal processing of traffic police who had been exposed to traffic noise for a

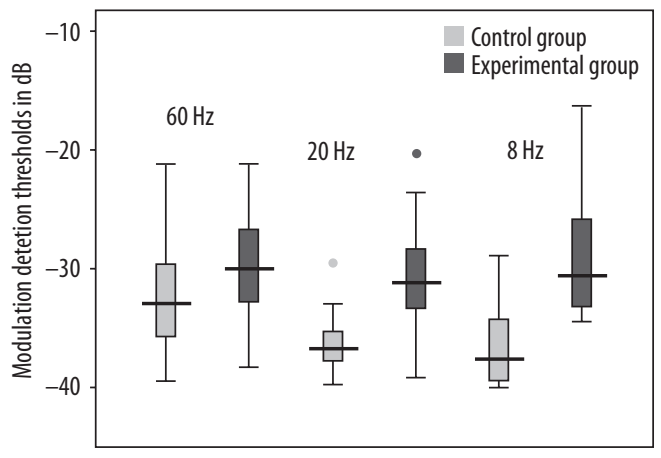

Figure 2. Modulation detection thresholds (in dB)obtained in traffic police officers and the control group. Error bars indicate standard deviations and circles indicate suspected outliers

long time with an age-matched control group. Statistical analysis revealed that there was no significant difference between the performances of both groups, except for modulation detection threshold at $20 \mathrm{~Hz}$. Though there is a general lack of reports on temporal processing ability in the population concerned, it has been reported that the incidence of noise-induced hearing loss is high in traffic police $[6,8]$. Study of the occupational hazards faced by police officers working outside reported that the incidence of naso-pharyngitis, arthropathy, photosensitive dermatitis, heat stroke, and noise-induced hearing loss in police working among traffic was higher than that of police working indoors [5]. Moreover, it is also known that continuous exposure to traffic noise can result in hypertension, ischemic heart disease, annoyance, and sleep disturbance [1].

Although the previous literature seemingly contradicts the present study's finding, it is worth recalling that the reported studies focused on the peripheral hearing mechanism whereas the current study focused on temporal processing. The absence of temporal processing deficits in the majority of temporal competence tests, as carried out in the present study, can be attributed to the various factors that control the effect of noise on the human system. The effect of noise on humans is reported to depend on multiple factors such as sound pressure level, spectral characteristics, hours of noise exposure per day, distance from the sound source, and individual susceptibility [9]. Unlike many other professionals who work in noisy environments, the 
level of surrounding noise varies over time in the present study population as the level depends on the traffic load, which varies with time [10]. Noise measurement studies carried out in an Indian city reported that the minimum and maximum traffic noise level to be $74 \mathrm{~dB}$ and $86 \mathrm{~dB}$ respectively on working days and $71 \mathrm{~dB}$ and $81 \mathrm{~dB}$ during holidays [11]. An earlier study also reported that exposure to $86.6 \mathrm{dBA}$ of music for half an hour did not give any statistically significant difference in otoacoustic emission parameters or pure tone thresholds [12]. Further, the damage risk criteria suggest an exposure to $85 \mathrm{dBA}$ noise for 8 hours to be the maximum permissible safe dose. Each traffic officer tested performed a daily duty amidst this variable traffic and traffic noise for 8 hours, and the mean duration of exposure was 8.2 years. Moreover, the distance from the sound source also varies in the population as the source and listener are mobile. Variability in the level of noise, distance between the source and the listener, and limited duration of exposure suggest a possible reason for absence of temporal processing deficit seen in the present study population. However, the present study population cannot be considered entirely free from occupational noise related harm as noise-induced peripheral hearing loss [5,6] and nonauditory effects of noise have been reported [1].

\section{Conclusions}

It can be concluded from the present study that exposure to regular traffic noise may not result in temporal processing deficits in traffic police officers as the effect is influenced by various factors like sound pressure level, spectral characteristics, duration of exposure, and distance from the source. However, the population cannot be considered free from noise-related harm as earlier studies have reported noise-induced hearing loss and nonauditory effects of traffic noise. Thus it is necessary to create awareness among traffic police regarding the possible harmful effect of noise on their health and recommend steps to reduce the noise exposure dose. The study adds to a long felt need for more research on various auditory and nonauditory effects of traffic noise.

\section{References:}

1. Basner MD, Bbisch W, Davis A, Brink M, Clark C, Janessen S, Stansfeld S. Auditory and non auditory effects of noise on health. Lancet, 2014; 383: 1325-32.

2. Kumar UA, Ameenudin S, Sangamanatha AV. Temporal and speech processing skills in normal hearing individuals exposed to occupational noise. Noise Health 2012; 14: 100-5.

3. Spoorthi ML, Sharmada K, Vikas MD. Effect of long term exposure to class room noise on temporal resolution and speech perception abilities. Proceedings of $47^{\text {th }}$ Indian Speech and Hearing Association Conference, 2015 Jan 1-3, Manipal, Karnataka, India.

4. Diaz J, Ekelund M, Gothe R, Huber M, Jordan A, Kallischnig $\mathrm{G}$ et al. Traffic Noise Pollution: A state-of-the-art review. European Commission, DG Health \& Consumer Protection, Luxembourg, 2001. Available at http://ec.europa.eu/health//sites/ health/files/healthy_environments/docs/traffic_noise.pdf.

5. Li YC, Huang HJ, Zhang ZL, Qi XY. Effect of occupation on health of traffic policemen in a city. Zhonghua Lao Dong Wei Sheng Zhi Ye Bing Za Zhi, 2008; 26 (3): 165-67 [in Chinese].

6. Lesage FX, Jovenin N, Deschamps F, Vincent S. Noise induced hearing loss in French police officers. Occupational Medicine, 2009; 59(7): 483-86.
7. Grassi M, Soranzo A. MLP: A MATLAB toolbox for rapid and reliable auditory threshold estimation. Behav Res Methods, 2009; 41: 20-28.

8. Kyaw NW, Nayake BPB, Min ZL, Alice Lai. Noise induced hearing loss in the police force. Safety Health Work, 2015; 6(2): 134-38.

9. Johnson DL, Papadopoulos P, Watfa N, Takala. Exposure criteria, occupational exposure levels. In: B. Goelzer, C. H. Hansen, and G. A. Sehrndt, editors. Occupational Exposure to Noise: Evaluation, prevention and control. Dortmund/Berlin: World Health Organization, 2001; 79-102.

10. Shukla SP, Yadav SK, Lohani B, Biswas S, Behra SN, Singh NB et al. Characterization of traffic noise for a typical Indian road crossing. Current Science, 2012; 103(10): 1193-201.

11. Bhosale BJ, Late A, Nalawade PM, Chavan SP, Mule PB. Studies on assessment of traffic noise level in Aurangabad city, India. Noise Health, 2010; 12(48): 195-98.

12. Trzaskowski B, Jędrzejczak WW, Piłka E, Cieślicka M, Skarżyński H. Otoacoustic emissions before and after listening to music on a personal player. Med Sci Monit, 2014; 20: 1426-31. 